\title{
Effect of Tamoxifen on the Level of the Gonadotrophins, Estrogen and Progesterone Hormones pre and post Implantation in the Rats*
}

\author{
Ahmed R. Al-Himaidi, Ibrahim M. Al-Hazza, \\ Samir A.E. Bashandy and Ismaaell H. Aty \\ Zoology Dept., College of Science, King Saud University, \\ Riyadh, Saudi Arabia
}

\begin{abstract}
Tamoxifen was given orally to two groups of pregnant female rats $(0.4 \mathrm{mg} / \mathrm{kg} /$ day). First group before implantation -(day 1-3 post coitus), and the second after implantation (day $-7-9$ post coitus) with a control group given a saline only. After the last day of treatment blood samples were collected from the eye blood vessel of the females. The analysis of the gonadotrophin hormones (FSH, LH) and the sex hormones (Progesterone and Estrogen) were done by hormones kit. In both female groups (before and after implantation) the level of (FSH) was significantly decreased $(\mathrm{P}<0.001 ; 4.22 . \pm 0.76 \mu \mathrm{l} /$ $\mathrm{ml}$ and $\mathrm{p}<0.05 ; 1.79 \pm 0.38 \mathrm{ml} / \mathrm{ml}$ respectively) as compared to the control group $(16.11 \pm 2.26 \mathrm{ml} \mu / \mathrm{ml}$ and $3.28 \pm 0.34$ before and after implantation respectively). While in the second group (post implantation) there were no significant effects of tamoxifen treatment on the levels of other hormones between both treated and control groups. There were some changes in hormone levels between the pre and post implantation, except the estrogen remain at the same level in all groups. The study indicates that tamoxifen acts differently (directly or indirectly) at the level of sex or gonadotrophin hormones.
\end{abstract}

Keywords: Tamoxifen, FSH, LH, Estrogen, Progesterone and Implantation.

\section{Introduction}

The anti-estrogen (Z)-1-\{4-[(dimethylamino)ethoxy] phenyl\}-1-1-diphenyl-1butene (tamoxifen) is a drug wildly used for the adjuvant therapy in the treatment of women with estrogen receptor-positive breast tumors and has a low in-

\footnotetext{
* This research was granted by College of Science Research Center at King Saud University, Grant no. Zool/ $01 / 1423$.
} 
cidence of serious side effects ${ }^{[1]}$. Tamoxifen was discovered more than 40 years ago as an anti-estrogen to be used as a contraceptive drug, but clinical application as postcoital contraceptive was found to be inappropriate ${ }^{[2,3]}$. Epidemiological data indicated that in women taking tamoxifen there was an increased risk of endometrial cancer ${ }^{[4,5]}$. The successful introduction of tamoxifen for the treatment of breast cancer ${ }^{[6,7]}$ provided the incentive for a renewed investigation of the structure-activity relationships of anti-estrogen ${ }^{[2]}$. It has been reported that tamoxifen and its more active metabolite 4-hydroxytamoxifen induce multiple cellular effects, including anti-oxidant action ${ }^{[8,9,10]}$. A relatively large body of literature is available on the relationship between progesterone/estrogen and early embryonic development. Niemann and his coworker ${ }^{[11]}$, did a review about the role of estrogen in early embryonic development. The Ci-628 citrate a specific estrogen antagonist (1-5 ug/ml of culture media), significantly inhibit the transformation of morulae to blastocysts of the rabbit embryos ${ }^{[12]}$. The exposure of tamoxifen during pregnancy increases carcinogen-induced mammary tumorigenesis among rat offspring ${ }^{[13]}$. Also it has an effect of the chromosomal level ${ }^{[14]}$ and tamoxifen has a salubrious effect on the serum marker enzyme, glycoprotein's, lysosomal enzymes level in breast cancer women ${ }^{[15]}$.

Tamoxifen-induced alteration in meiotic maturation and cytogenetic abnormalities in mouse oocytes and 1-cell zygotes ${ }^{[14]}$. Tamoxifen prevent the implantation of the mice embryos if the pregnant females were treated (10 $\mathrm{mg}$ single dose) before implantation, with no side effect on the embryo post the implantation ${ }^{[16]}$. Tamoxifen increases membrane fluidity at high concentrations ${ }^{17]}$. Chronic tamoxifen treatment via oral or s.c. routes reduced the fertility of the male rat, weight of accessory sex glands, serum luteinizing hormone, and testosterone level without altering potency or sperm counts ${ }^{[18]}$. Intermittent oral tamoxifen administration completely suppressed the fecundity of adult male rats with reserved potency ${ }^{[19]}$. There are contradictory results in the literature relating to the effect of tamoxifen in fertility and reproductions, and the reproductive hormone, from the pituitary gland (FSH and LH) and the sex hormone, from the gonads (Estrogen and Progesterone) has a fundamental roles in the fertility and reproduction. The aim of this study is to detect the effect of the tamoxifen on the levels of the reproductive and sex hormones before and post implantation of the rat females.

\section{Materials and Methods}

\section{Animals}

Groups of rat females and males brought from animal house at College of Pharmacy, King Saud University. Females were housed with male $(4+1)$ for mating in plastic cages in an environmentally controlled room with $25^{\circ} \mathrm{C}, 10$ hours light and 14 hours dark cycle. The animals were fed Pillsbury food and 
had free access to water. Pregnancy was confirmed by presence of vaginal plug daily. The pregnant females were separated from others and that day was counted as day zero of pregnancy.

\section{Tamoxifen Treatment}

The tamoxifen tablets (Nolvadex) was purchased from Zenec Limited U.K. The tablet was prepared in distilled water $(10 \mathrm{mg}$ in $10 \mathrm{ml}$ water as suspension solution). Tamoxifen $(10 \mathrm{mg} / \mathrm{kg}$ ) was administered orally (via force feeding tube) to two groups of females (10 each) for three days. First group treated before implantation (from day 3-6 post copulation) and the second group post implantation (from day 7-9 post copulation). Two control groups of females (10 each) were given distilled water only (first from day 3-6 and second group from day 7-9 post copulation).

\section{Blood Sample Collections}

After one day of the last treatment of each female group (day 4 for the first group and day ten of the second group), blood samples were collected (in heparin treated capillary tubes) from the retro- orbital plexus in the eye capillary of the females. The blood samples were centrifuged and the plasma were separated and cooled in freezer until analysis.

\section{Assay of The Serum Hormone Samples}

The level of the follicle stimulating hormone (FSH), Luteinzing hormone $(\mathrm{LH})$, estrogen and progesterone were analyzed in the collected blood serum sample, using the Alpha Scientific USA, hormone kits.

The assay of the hormones is based at the principle of competitive binding between the hormone in the test specimen and hormone-enzyme conjugate for a constant amount of rabbit anti-hormone.

\section{Statistical Analysis}

The statistical analysis of the data was done by t-test, ANOVA and Chisquare analysis to compare between each two means of each treatment . All calculations were done by computer using in stat program.

\section{Results}

In the first treated female group (10 $\mathrm{mg} / \mathrm{kg} / \mathrm{day}$ tamoxifen), after copulation, and before implantation (from day 3-6) show a significantly very low level of FSH $(\mathrm{P}<0.001)(4.22 \pm 0.75)$ compared with the control group $(16.11 \pm 2.25$ 
$\mathrm{mlU} / \mathrm{ml})$. Similar result was recorded in case of after implantation $(\mathrm{P}<0.05$, $1.79 \pm 0.38$ as compared to control group $(3.28+0.34)$. FSH level of the treated rats with tamoxifen decreased by $73.81 \%$ and $45.43 \%$ before and after implantation respectively, Table 1 . The level of circulating $\mathrm{LH}$ were reduced in the second group compared with the first group. While all other hormones (LH, Progesterone and Estrogen) show the same level in both treated and control females (Tables 1 and 2). The results in Tables (1 and 2), also indicate no differences between the treated and control females (post implantation day 9-12) in the levels of all hormones (FSH, LH, Progesterone, Estrogen). The level of estrogen hormone remained at the same level $(\sim 10.33 \pm 0.33$ to $10.77 \pm 0.62 \mathrm{pg}$ $/ \mathrm{ml}$ ) in all treated and controls females (pre and post implantation females). The level of progesterone hormone remained higher at all times in the pre and post implantation groups $(22.66 \pm 2.91-16.55 \pm 2.32 \mathrm{ng} / \mathrm{ml})$; with no significant differences between the treated and control groups, Table 2 .

TABLE 1. The effect of tamoxifen on the level of serum pituitary hormones (FSH, LH) before and after implantation in pregnant rats.

\begin{tabular}{|c|c|c|c|}
\hline $\begin{array}{c}\text { Treatment with }(10 \mathrm{mg} / \mathrm{kg}) \\
\text { tamoxifen single dose/day }\end{array}$ & $\begin{array}{c}\text { Type of } \\
\text { treatment }\end{array}$ & $\begin{array}{c}\text { Level of FSH } \\
\text { Mean }+ \text { SEM }(\mu / \mathrm{ml})\end{array}$ & $\begin{array}{c}\text { Level of LH } \\
\text { Mean }+ \text { SEM }(\mu / \mathrm{ml})\end{array}$ \\
\hline $\begin{array}{l}\text { Before implantation } \\
\text { (from day 3-6) }\end{array}$ & Treated & $4.222^{* *} \pm 0.757$ & $4.8 \pm 0.854$ \\
\hline & $\begin{array}{c}\text { Control } \\
\text { \% of change }\end{array}$ & $\begin{array}{c}16.111 \pm 2.257 \\
-73.81\end{array}$ & $\begin{array}{l}7.07 \pm 1.397 \\
-32.20\end{array}$ \\
\hline $\begin{array}{l}\text { After implantation } \\
\text { (from day 9-12) }\end{array}$ & Treated & $1.789^{* *} \pm 0.380$ & $3.244^{*} \pm 0.748$ \\
\hline & $\begin{array}{c}\text { Control } \\
\% \text { change }\end{array}$ & $\begin{array}{c}3.278^{* *} \pm 0.343 \\
-45.43\end{array}$ & $\begin{array}{l}2.588^{*} \pm 0.696 \\
-21.35\end{array}$ \\
\hline
\end{tabular}

\footnotetext{
** Significantly different from control before at $(\mathrm{P}<0.001)$.

* Significantly different from control before at $(\mathrm{P}<0.05)$.

$\%$ of change is relative to the control value.
}

\section{Discussion}

The effect of the tamoxifen on lowering the level of FSH in the preimplantation treated females, could be attributed to inhibition effect of estrogen in pituitary gland. But the intermittent treatment of male rats with tamoxifenon has no effect on FSH and estradiol ${ }^{[19]}$. 
TABLE 2. The effect of tamoxifen on the level of serum ovary hormones (estrogen and progesterone) before and after implantation in pregnant rats.

\begin{tabular}{|l|c|c|c|}
\hline $\begin{array}{l}\text { Treatment with }(10 \mathrm{mg} / \mathrm{kg}) \\
\text { tamoxifen single dose/day }\end{array}$ & $\begin{array}{c}\text { Type of } \\
\text { treatment }\end{array}$ & $\begin{array}{c}\text { Level of estrogen } \\
\text { Mean }+ \text { SEM }(\mathrm{pg} / \mathrm{ml})\end{array}$ & $\begin{array}{c}\text { Level of progesterone } \\
\text { Mean + SEM }(\mu / \mathrm{ml})\end{array}$ \\
\hline $\begin{array}{l}\text { Before implantation } \\
\text { (from day 3-6) }\end{array}$ & Treated & $10.778 \pm 0.618$ & $22.667 \pm 2.915$ \\
\hline & $\begin{array}{c}\text { Control } \\
\text { \% of change }\end{array}$ & $\begin{array}{l}10.889 \pm 0.484 \\
-1.0\end{array}$ & $\begin{array}{l}16.556 \pm 2.328 \\
+36.9\end{array}$ \\
\hline $\begin{array}{l}\text { After implantation } \\
\text { (from day 9-12) }\end{array}$ & Treated & $10.333 \pm 0.380$ & $16.377 \pm 3.293$ \\
\hline & $\begin{array}{c}\text { Control } \\
\text { \% change }\end{array}$ & $\begin{array}{l}10.444 \pm 0.337 \\
-1.05\end{array}$ & $\begin{array}{l}23.667 \pm 2.55 \\
-30.80\end{array}$ \\
\hline
\end{tabular}

$\%$ of change is relative to the control value.

Tamoxifen prevents the implantation of the mice embryos in the endometrium, it might work on the uterine wall growth hence it prevents the implantation as it is indicated by ${ }^{[2]}$ that the anti-estrogen action in the uterus is based upon the inhibition of estrogen stimulated uterine growth ${ }^{[16]}$. Tamoxifen interferes with the attachment (binding) of estrogen to its receptor in the uterus hence it increases its level in the serum. The result of this study did show that the anti-estrogenic drug tamoxifen, is efficient inhibitor of estrogen binding to its receptor and causes the constant level of estrogen in the pregnant rat females (pre and post implantation treatment). Although the lower level of LH did not show significant differences in both treated and control female groups in our study, compared to chronic male treatment study by Gill-Sharma and coworker, that it lower the level of serum luteinizing hormone, and testosterone level without altering potency or sperm counts ${ }^{[18,19]}$. The oral treatment, might alter sex variation and the hepatic metabolism of tamoxifen compared to the sub. c treatment. A significant decrease in circulating LH and testosterone levels without any change in the levels of FSH and estradiol was observed in male rats administered tamoxifen ${ }^{[20]}$. Tamoxifen treatment produced a significant increase in gonadotropins in adult monkeys while serum testosterone levels were normal ${ }^{[21]}$. Administration of tamoxifen to pregnant mice result in reproductive toxicity in female offspring ${ }^{[22]}$.

\section{Acknowledgment}

We are grateful to the research center at the College of Science, King Saud University for granting this work (Grant no. Zoo/01/1423). 


\section{References}

1. White Ian, N.H., "The tamoxifen dilemma", Carcinogenesis Vol . 20(2): (1999) 1153-1160.

2. Jordan, V.C., "Biochemical pharmacology of anti-estrogen action." Pharmacol. Res. 36: (1984) 245-267.

3. Jordan, V.C., "Designer estrogen" Sci. Am. 279: (1998) 36-43.

4. Fomander, T., Cedermark, B. and Mattsson, A., "Adjuvant tamoxifen in early breast cancer: occurrence of new primary cancers." Lancet. 1: (1989)117-119.

5. Rutqvist, L., Johansson, H., Signomklao, T., Johansson, U., Fomonder, T. and Wilking, N., "Adjuvant tamoxifen therapy for early stage breast cancer and second primary malignancies". J. National Cancer Inst. 87: (1995) 645-651.

6. Mouridsen, H., Palshof, T., Patterson, J. and Batersby, L. "Tamoxifen in advanced breast cancer". Cancer Treat. Rev. 5: (1978) 143-241.

7. Ward, H.W.C., "Anti-oestrogen therapy for breast cancer - A trial of tamoxifen at two dose levels". Br. Med. J. 1: (1973) 13-14.

8. Kemp J., Adam, H., Wakling, A. and Slater, R., "Identification biological activity of tamoxifen metabolites in human serum". Biochem. Pharmacol. 32 (1983): 2045-2052.

9. Wiseman, H., Laughton, M., Arnstein, H., Cannon, M. and Halliwell, B., "The antioxidant action of tamoxifen and its metabolites, Inhibition of lipoperoxidation". FEBS. Lett. 236 (1990) 192-194.

10. Wiseman, H., Cannon, M., Arnstein, H. and Halliwell, B., Mechanism of inhibition of lipid peroxidation by tamoxifen, and 4-hydroxytamoxifen introduced in liposomes". FEBS. Lett 274: (1990) 107-110.

11. Niemann H., Freitag, M. and Elsaesser, I., "The role of oestrogen in early embryonic development." J. Reprod. Fert., Suppl. 38: (1989) 73-83.

12. Paria, B.C., Sengupta, J. and Manchanda, S.K., "Role of embryonic oestrogen in rabbit blastocyst development and metabolism”, J. Reprod. Fert. 70: (1984) 429-436.

13. Halakivi-Clarke L., Cho, E., Onojafe, I., Liao, D. and Clarke R., "Maternal exposure to tamoxifen during pregnancy increases carcinogen-induced mammary tumorigenesis among female rat offspring." Clin. Cancer Res. 8: (2000) 385-388.

14. London, S. and Mailhes, J., "Tamoxifen-induced alteration in meiotic maturation and cytogenetic abnormalities in mouse oocytes and 1-cell zygotes". Zygote. 9 (2001) 97-104.

15. Thangaraju, M., Rameshbabu, J., Vasavi, H., Ilanchezhian, S. and Vini Schdanandam, P., "The salusbrious effect of tamoxifen (correction of tamoxifen) on serum marker, glycoproteins, lysosomal enzymes level in breast cancer women.” Mol. Cell Biochem. 185 (1998) 85-94.

16. Alhimaidi A., "Tamoxifen prevent the implantation of the mice embryo with no side effect post implantation". J. King Saud Univ. Sci., 16: (2003) 1-6.

17. Severcan, F., Kazanci, N. and Zorlu, F., "Tamoxifen increases membrane fluidity at high concentrations". Bioscience Reports. 20(3): (2001) 177-184.

18. Gill-Sharma, M.K., Balasinor, N., Parte P., Aleem M. and Juneja H.S., "Effect of tamoxifen metabolites on the fertility of male rat". Contraception 63: (2) (2001) 103-109.

19. Gill-Sharma, M.K., Balasinor, N. and Parte P., "Effect of intermittent with tamoxifen on reproduction in male rats". Asian J. Androl. 3: (2001) 115-119.

20. Gill-Sharma, M.K., Gopatkrishnan, K., Balasinor, N., Parte, P.J., Jayaraman, S. and Juneja, H.S., Effect of tamoxifen on the male rats. J. Fertil. 99: (1993); 399-402.

21. Gill-Sharma, M.K., D'Souza, S., Parte, P., Balasinor, N., Chudhuri, J., Majramkar O., Aleem, M. and Juneja, H.S., "Effect of oral tamoxifen on semen characteristic and serum hormone profile in male bonnet monkeys". Contraception 67: (2003) 409-413.

22. Sanders, J.M. and Cunningham, M.L., "Determination of tamoxifen and metabolites in mouse fetal tissue using nonaqueous capillary electrophoresis". Electrophoresis. 23: 9 (2002) $502-505$ 


\section{تأثير التماكسوفين على مستوى الهرمونات التناسلية وهرمون

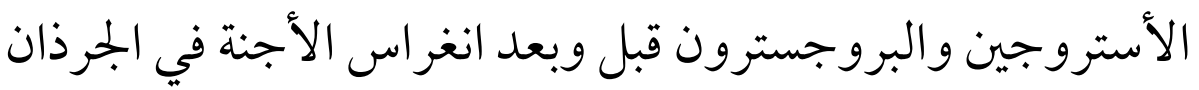

أحمد الحميدي ، و إبر اهيم الهزاع ، و سمير بشندي ، و إسماعيل عاتي

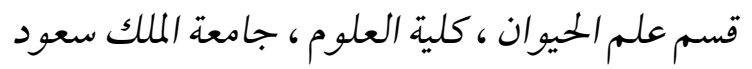

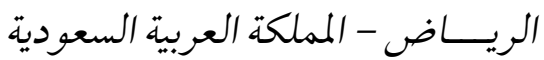

EMail:ahimaidi@ksu.edu.sa : البريد الإلكتروني

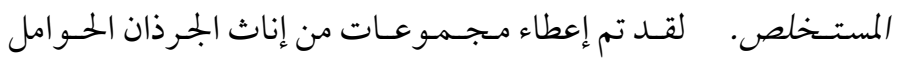

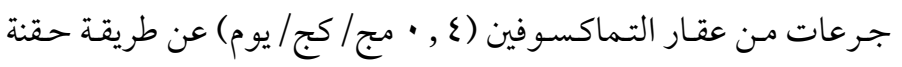

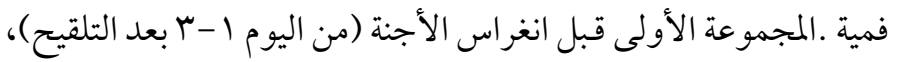

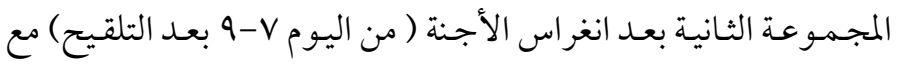

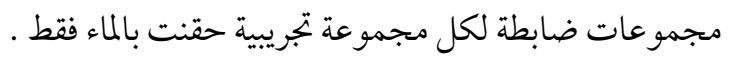

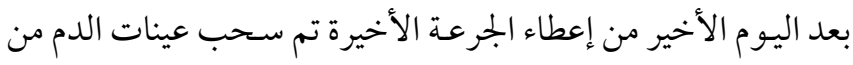

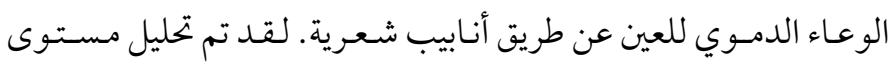

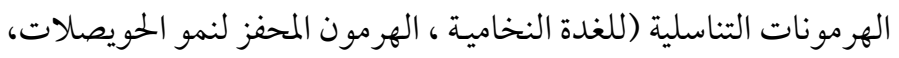

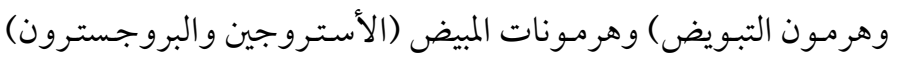
بواسطة أطقم خاصة لتحليل الهرمونات .

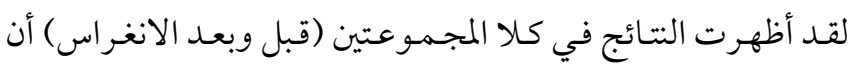

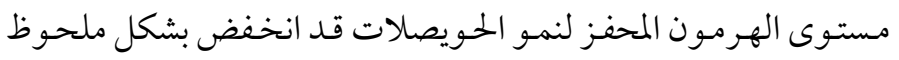

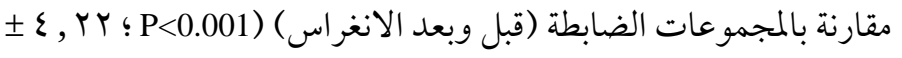

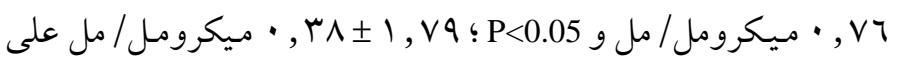

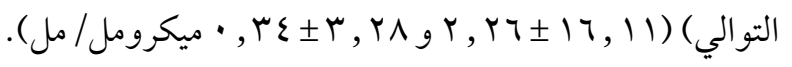

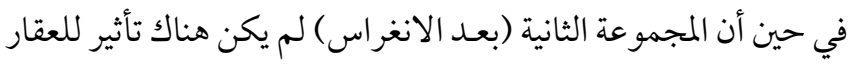

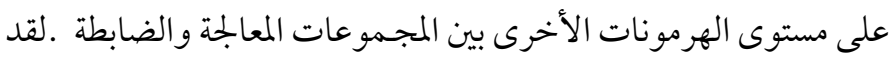

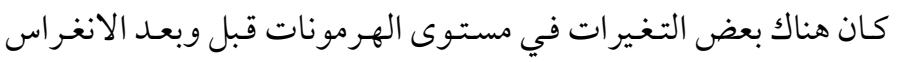




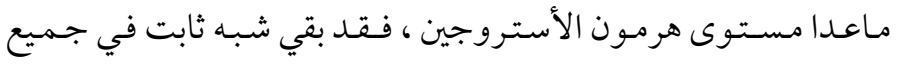

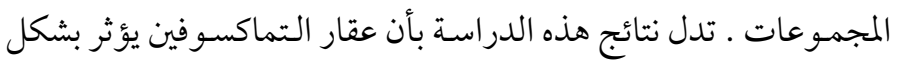

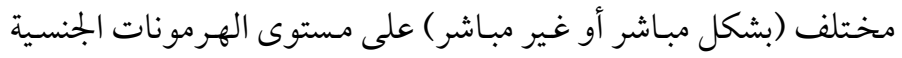

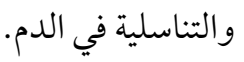

